\title{
Anaphylactic Shock Due to Allergy to Macrogol 4000 Contained in SonoVue ${ }^{\circledR}$
}

\section{Nagore Arruti Oyarzabal, Natividad Longo Areso, Nagore Bernedo Belar, Italo Girao Popolizio, Arturo Velasco Arregui, Olga Villarreal Balza de Vallejo}

Allergy and Clinical Immunology Department, Araba University Hospital, Vitoria-Gasteiz, Spain

Email: nagore_arruti@hotmail.com

How to cite this paper: Oyarzabal, N.A, Areso, N.L., Belar, N.B., Popolizio, I.G., Arregui, A.V. and de Vallejo, O.V.B. (2017) Anaphylactic Shock Due to Allergy to Macrogol 4000 Contained in SonoVue. Case Reports in Clinical Medicine, 6, 143-147. https://doi.org/10.4236/crcm.2017.66014

Received: May 17, 2017

Accepted: June 16, 2017

Published: June 19, 2017

Copyright (ङ 2017 by authors and Scientific Research Publishing Inc. This work is licensed under the Creative Commons Attribution International License (CC BY 4.0). http://creativecommons.org/licenses/by/4.0/

\begin{abstract}
SonoVue ${ }^{\varpi}$ (Bracco; Milan, Italy) is an ultrasound contrast medium which contains polyethylene glycol (PEG) or macrogol, an excipient responsible for severe allergic reactions, especially through the parenteral route, and widely used, especially in the health field. We present an adult patient who experienced an IgE-mediated anaphylactic shock due to macrogol contained in SonoVue ${ }^{\oplus}$, as demonstrates the skin tests realized. The allergy study has been useful in our case because it has guided us in the preventive measures to advice to the patient, who has to avoid not only SonoVue but also other products that contain macrogol. We consider this case of interest because it is an allergic adverse reaction to SonoVue ${ }^{\varpi}$ in which its excipient, macrogol, has acted like the allergen responsible. We have to add SonoVue ${ }^{\oplus}$ to the list of the products that contain macrogol in their composition and keep in mind the possible allergenic capacity of this excipient for suspecting its responsibility, especially in those patients with multiple drug allergy and/or reactions to products of different natures like ultrasound gels, topical products (e.g. toothpastes, antiseptics, sunscreens, etc.), plasma expanders and others.
\end{abstract}

\section{Keywords}

SonoVue ${ }^{\oplus}$, Macrogol, Polyethylene Glycol (PEG), Tween 80, Ultrasound Contrast Agents, Allergy

\section{Introduction}

SonoVue (Bracco; Milan, Italy) is an ultrasound contrast agent used clinically in Europe to enhance ultrasound images in echocardiography and Doppler macrovasculature or microvasculature [1]. It is a suspension of phospholipid-stabilized microbubbles containing sulfur hexafluoride $\left(\mathrm{SF}_{6}\right)$ gas. This injectable solution is prepared mixing a powder (formed by macrogol 4000, distearoylphosphatidyl- 
choline, dipalmitoylphosphatidylglycerol sodium and palmitic acid) with a solvent (sodium chloride $0.9 \%$ ). Among the adverse effects of SonoVue ${ }^{\varpi}$ have been described anaphylactic shock [2] [3] and Kounis syndrome [4] cases. Levano et al. describe a non-IgE-mediated anaphylactic shock due to SonoVue ${ }^{\circledast}$ and hypothesize that the possible underlying mechanisms of this adverse reaction could be the direct mast cell activation or complement activation, among others [2]. Dijkmans et al. suggest the existence of a hypersensitivity reaction to PEG contained in SonoVue ${ }^{\circledast}$ in other cases [5]. Nevertheless, few articles mention the realization of an allergy study in order to elucidate this point [2].

\section{Case Report}

We present the case of a 59-year-old man who was in follow-up by the Cardiology Department due to a long ago diagnosed dilated cardiomyopathy, probable ischemic, with low ejection fraction. Years after the diagnosis, he suffered an acute coronary syndrome with ST elevation that requires percutaneous coronary intervention and cardiac rehabilitation. This patient was atopic and had no previous history of drug allergy. After completion of the cardiac rehabilitation, he experienced dizziness, blurred vision, profuse sweating, shaking chills, dyspnea, heat sensation in the neck and head, pain in the legs and hypotension (blood pressure, $80 / 50 \mathrm{mmHg}$ ) during the performance of a follow-up contrast echocardiogram, a few minutes after the infusion of SonoVue ${ }^{\bullet}$. He had no changes in heart and respiratory rates, ECG or cardiopulmonary auscultation. He had no cutaneous symptoms. The patient was treated with fluids, corticosteroids, antihistamines and oxygen at 35\%, improving in $4-6$ hours with no need of hospitalization. The serum tryptase was increased $(17.7 \mu \mathrm{g} / \mathrm{L}$ at 30 minutes and 15.8 $\mu \mathrm{g} / \mathrm{L}$ at 2 hours after the start of the symptoms). Two months before he received a contrast, probably the same.

The allergy study, summarized in Table 1, included: 1) Skin tests with Sono$\mathrm{Vue}^{\circledast}$ (as previously described [2]), different molecular mass macrogols and Tween 80, and 2) Basophil activation test (BAT) with Casenlax ${ }^{\oplus}$ (macrogol 4000), using CD63 expression as basophil activation marker. Skin prick tests

Table 1. Describes the form in which the different substances were tested in skin tests and BAT, and the results of these tests in our patient.

\begin{tabular}{|c|c|c|c|c|}
\hline \multicolumn{5}{|c|}{ Table 1. Allergy study } \\
\hline & Skin tests & Skin tests results & BAT & BAT results \\
\hline SonoVue & $\mathrm{SPT}$ as is & $(+)$ & & \\
\hline Macrogol $400\left(\right.$ Systane $\left.^{\oplus}\right)$ & $\mathrm{SPT}$ as is & $(-)$ & & \\
\hline Macrogol 3350 & $\mathrm{SPT}$ as is & $(+)$ & & \\
\hline Macrogol 4000 (Casenlax $\left.{ }^{\circledast}\right)$ & $\mathrm{SPT}$ as is & $(+)$ & $\begin{array}{l}\text { At } 1 \mathrm{mg} / \mathrm{ml} \text {, and } \\
\text { At } 0.5 \mathrm{mg} / \mathrm{ml} \text { concentration }\end{array}$ & $\begin{array}{l}(-) \\
(-)\end{array}$ \\
\hline Tween 80 & $\begin{array}{l}\mathrm{SPT} \text { at } 0.04 \mathrm{mg} / \mathrm{ml} \\
\mathrm{IDT} \text { at } 0.004 \mathrm{mg} / \mathrm{ml}\end{array}$ & $\begin{array}{l}(-) \\
(-)\end{array}$ & & \\
\hline
\end{tabular}

SPT: skin prick test; IDT: intradermal test; BAT: basophil activation test; (+): positive; (-): negative. 
(SPT) with SonoVue ${ }^{\circledast}$, macrogol 3350 and macrogol 4000 were positive. SPT with macrogol 4000 was negative in 10 controls. BAT was also negative.

We did not perform oral challenge test with PEG and we could not complete the study with the determination of baseline serum tryptase and specific IgE to ethylene oxide.

\section{Discussion}

Polyethylene glycols (PEG) or macrogols are widely used in medical, pharmaceutical, cosmetic, industrial and food products. The polymerization of ethylene oxide produce PEG polymers $\left[\mathrm{H}\left(\mathrm{OCH}_{2} \mathrm{CH}_{2}\right)_{\mathrm{n}} \mathrm{OH}\right]$ that vary in chain length and molecular mass (MM), generating low MM PEG (<400 g/mol) or high MM PEG ( $>1000 \mathrm{~g} / \mathrm{mol})$. Physiological absorption decreases with increasing $M$ (e.g. through gastrointestinal mucosa) [6]. It is important to point out that crossreactivity between PEG, PEGylated drugs (systemic drugs with PEG covalently attached) and PEG derivatives (structurally related polymers) exists as well as between some PEG derivatives (such as polysorbates and castor oils) [7].

Several anaphylactic cases due to high MM PEG have been described [8] [9] [10]. According to the data published in a review, all cases with parenteral (intra-articular, intramuscular o intravenous) or perioperative exposures developed anaphylaxis, in contrast to oral (36\%) and cutaneous exposures (0\%) [6]. Therefore, it is thought that hypersensitivity reactions severity may depend on PEG dose available for absorption and the exposure route. It is noteworthy that a $27 \%$ of patients developed hypersensitivity reactions by different routes of exposure, being likely that an individual reactivity-threshold exists for both dose and MM. All cases with positive SPT with responsible PEG showed also a positive SPT with a greater MM PEG of that tested positive, suggesting the absence of an upper limit for MM in regard to reactivity. Many allergic to PEG have positive SPT. There is a relatively high risk of systemic reactions following prick and intradermal tests [11] [12], so we think that intradermal tests should only be carried out for diagnosis when SPT with the product that contains PEG, tested as is, is negative. Some authors have completed the study of these adverse reactions doing BAT with PEG, with different results [12] [13] [14]. In our case, BAT was negative, having been the skin tests more useful for diagnosis.

\section{Conclusion}

The allergy study performed in our patient suggests an IgE-mediated reaction to SonoVue ${ }^{\circledast}$ due to allergy to an excipient (macrogol 4000). We do not find in the literature any article which has demonstrated the IgE-mediated mechanism in the adverse reactions described with SonoVue ${ }^{\bowtie}$. We advised the patient to avoid Sonovue $^{\circledast}$ and other high MM PEG containing products, and to be aware of the many commonly used products that contain macrogol, as drugs (e.g. parenteral corticosteroids, anti-inflammatory drugs, antibiotics, etc.), laxative solutions, ultrasound gels, throat lozenges, topical products (e.g. toothpastes, antiseptics, sunscreens, etc.), plasma expanders, wound dressings, etc. The patients sensi- 
tized to both low and high MM PEG should be especially prevented.

\section{Acknowledgements}

No external funding was received for the present study.

\section{Competing Interests}

The authors declare that they have no conflicts of interest.

\section{Authors' Contributions}

All authors have been involved in drafting the manuscript and revising it critically, giving final approval of the version to be published.

\section{References}

[1] Cheng, K.T. (2004-2013) Stabilized Sulfur Hexafluoride Microbubbles. Molecular Imaging and Contrast Agent Database (MICAD) [Internet]. National Center for Biotechnology Information (US), Bethesda, MD.

[2] Levano, J.A., Jimenez, M.A., Laiseca, A. and Vives, R. (2012) Anaphylactic Shock Due to SonoVue. Annals of Allergy, Asthma \& Immunology, 108, 208-209. https://doi.org/10.1016/j.anai.2011.12.011

[3] Solivetti, F.M., Elia, F., Musicco, F., Bonagura, A.C., Di Leo, N., Iera, J., et al. (2012) Anaphylactic Shock Induced by Sulphur Hexafluoride in an Individual with No History of Heart Disease: Case Report and Literature Review. Ultraschall in der Medizin, 33, 597-598. https://doi.org/10.1055/s-0032-1313141

[4] Van Ginkel, A.G., Sorgdrager, B.J., de Graaf, M.A., Karalis, I. and Ajmone Marsan, N. (2014) ST-Segment Elevation Associated with Allergic Reaction to Echocardiographic Contrast Agent Administration. Netherlands Heart Journal, 22, 77-79. https://doi.org/10.1007/s12471-013-0440-9

[5] Dijkmans, P.A., Visser, C.A. and Kamp, O. (2005) Adverse Reactions to Ultrasound Contrast Agents: Is the Risk Worth the Benefit? European Journal of Echocardiography, 6, 363-366. https://doi.org/10.1016/j.euje.2005.02.003

[6] Wenande, E. and Garvey, L.H. (2016) Immediate-Type Hypersensitivity to Polyethylene Glycols: A Review. Clinical \& Experimental Allergy, 46, 907-922. https://doi.org/10.1111/cea.12760

[7] Kang, S.Y., Sohn, K.H., Lee, J.O., Kim, S.H., Cho, S.H. and Chang, Y.S. (2015) Intravenous Tacrolimus and Cyclosporine Induced Anaphylaxis: What It Next? Asia Pacific Allergy, 5, 181-186. https://doi.org/10.5415/apallergy.2015.5.3.181

[8] Nguyen, V.M., Petitpain, N., Lovato, B., Terrier, P., Begon Bagdassarian, I., Sullerot, I., et al. (2014) Anaphylaxie au macrogol. À propos de 5 cas déclarés au Réseau Allergo-Vigilance. Revue Française d Allergologie, 54, 307-310. https://doi.org/10.1016/j.reval.2013.10.004

[9] Caballero, M.L., Lluch-Bernal, M., Vilà-Nadal, G., Lluncor, M. and Quirce, S. (2016) IgE-Mediated Anaphylaxis Induced by Macrogol 6000. Journal of Investigational Allergology and Clinical Immunology, 26, 398-400. https://doi.org/10.18176/jiaci.0089

[10] Brandt, N., Garvey, L.H., Bindslev-Jensen, U., Kjaer, H.F., Bindslev-Jensen, C. and Mortz, C.G. (2017) Three Cases of Anaphylaxis Following Injection of a Depot Corticosteroid with Evidence of IgE Sensitization to Macrogols Rather than the Active 
Steroid. Clinical and Translational Allergy, 7, 2.

https://doi.org/10.1186/s13601-016-0138-3

[11] Hesselbach, C., Bohning, W. and Wettengel, R. (1990) Anaphylactic Shock after Sucking on a Throat Lozenge. Deutsche Medizinische Wochenschrift, 115, 1397 1399. https://doi.org/10.1055/s-2008-1065170

[12] Borderé, A., Stockman, A., Boone, B., Franki, A.S., Coppens, M.J., Lapeere, H., et al. (2012) A Case of Anaphylaxis Caused by Macrogol 3350 after Injection of a Corticosteroid. Contact Dermatitis, 67, 376-378. https://doi.org/10.1111/j.1600-0536.2012.02104.x

[13] Badiu, I., Guida, G., Heffler, E. and Rolla, G. (2015) Multiple Drug Allergy Due to Hypersensitivity to Polyethylene Glycols of Various Molecular Weights. Journal of Investigational Allergology and Clinical Immunology, 25, 368-369.

[14] Bommarito, L., Mietta, S., Nebiolo, F., Geuna, M. and Rolla, G. (2011) Macrogol Hypersensitivity in Multiple Drug Allergy. Annals of Allergy, Asthma \& Immunology, 107, 542-543. https://doi.org/10.1016/j.anai.2011.08.008

Submit or recommend next manuscript to SCIRP and we will provide best service for you:

Accepting pre-submission inquiries through Email, Facebook, LinkedIn, Twitter, etc. A wide selection of journals (inclusive of 9 subjects, more than 200 journals) Providing 24-hour high-quality service User-friendly online submission system Fair and swift peer-review system Efficient typesetting and proofreading procedure Display of the result of downloads and visits, as well as the number of cited articles Maximum dissemination of your research work

Submit your manuscript at: http://papersubmission.scirp.org/

Or contact crcm@scirp.org 